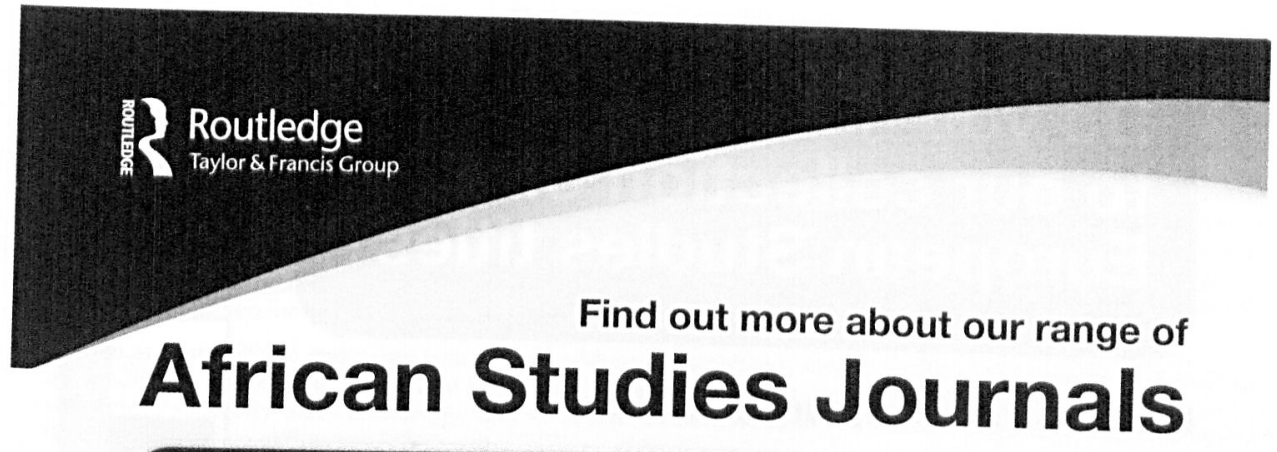

Routledge African Studies journals publish articles on a range of subjects across area studies, cultural studies, political economy, African history, literature, development, international affairs and human rights, as well as many others.

We are happy to present to you a selection of the African Studies titles and invite you to visit the journal homepages online to gain free access to free articles and sample coples, to subscribe to the journal or to simply inform yourself as to the aims and scopes and submission policies of the journals

African and Black Diaspora www.tandfonline.com/rabd

Africa Review

www.tandfonline.com/rafr

African Studies

www.tandfonline.com/cast

Critical African Studies www.tandfonline.com/rcaf

Development

Southern Africa

www.tandfonline.com/dsa

International

Journal of African

Renaissance Studies

www.tandfonline.com/rars

\section{Journal of African}

Cultural Studies

www.tandfonline.com/jacs

Journal of Contemporary African Studies

www.tandifonline.com/cjca

\section{Journal of Eastern}

African Studies

www.tandfonline.com/rjea
The Journal of

North African Studies www.tandfonline.com/fnas

Journal of Southern African Studies www.tandfonline.com/isas

\section{Politikon}

www.tandfonline.com/cpsa
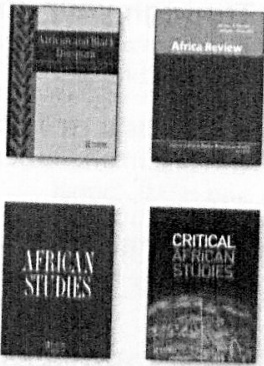

Review of African

Political Economy

www.tandfonline.com/roape

Safundi

www.tandfonline com/rsaf

Social Dynamics

www.tandfonline.com/rsdy
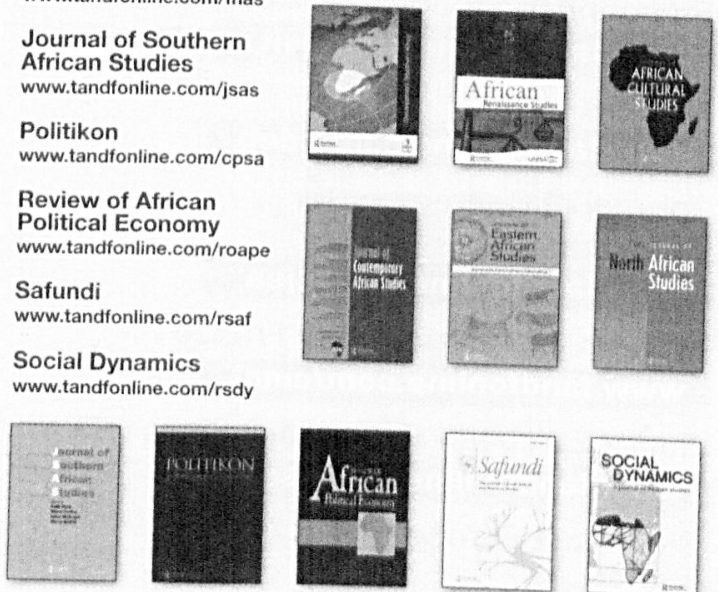


\section{Do you have access to our collection of European Studies titles?}

How can I access journal articles?

- Through your library - check with your librarian to see which journals you have access to and recommend a subscription to your Librarian

- Individual article download - create a profile at www.informaworld.com and purchase individual articles in PDF and HTML format

- Personal subscription - go to the individual journal homepage for more information

Contemporary French \&

Francophone Studies wwitandfonline.com/gsit

Debatte

wmw.tandfonline.com/cdeb

Journal of Contemporary

European Studies

imwtandfonline.com/cjea

Modern \& Contemporary France wmwtandronline.com/cmof

South European Society \& Politics wmwtandfonline.com/fses

Southeast European and Black Sea Studies

wwwtandfonline.com/ibss
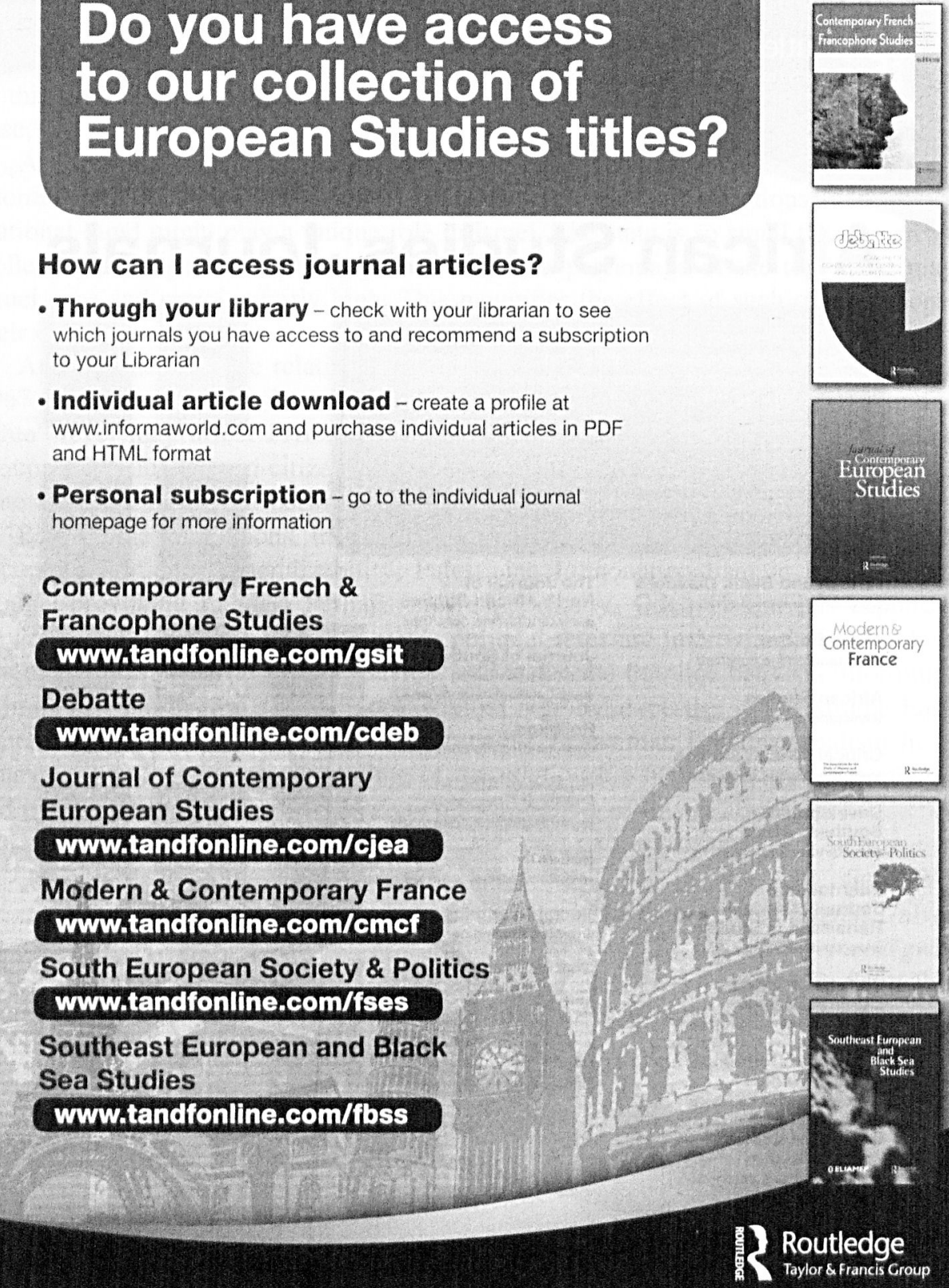

www.tandfonline.com/areastudies 
Nationalities Papers is the leading journal on nationalism, ethnicity, ethnic conflict and national identity in Central Europe, the Balkans, the former Soviet Union, the Caucasus, the Turkic world and Central Eurasia. Furthermore, the journal also publishes contributions on theories of nationalism, comparative studies of nationalism, and trans- and supranational aspects of interethnic relations and national identity. The journal publishes timely, high quality articles from a variety of disciplines, including history, political science, sociology, anthropology, and literature.

Nationalities Papers is the journal of the Association for the Study of Nationalities, bringing together scholars worldwide working on nationalism and ethnicity, Central and Eastern Europe, the Balkans and Eurasia.

All articles have undergone rigorous peer review, based on initial editor screening and double-blind refereeing by a minimum of two anonymous referees.

The journal welcomes submissions from multiple disciplines and different methodological approaches from scholars around the world. In addition to individual paper submissions, the journal also welcomes proposals for special symposia (3-5 articles) on specific regional or disciplinary themes. All symposia will undergo the same peer review process as other articles. Articles should be between 8,000 and 10,000 words in length (including notes and bibliography).

Inquiries. Direct all inquiries regarding articles and special symposia to the Editor: florian.bieber@uni-graz.at.

Electronic Submission. All submissions should be made online at the Nationalities Papers ScholarOne Manuscripts site (http://mc.manuscriptcentral.com/CNAP). New users should first create an account. Once a user is logged onto the site submissions should be made via the Author Centre. Authors should prepare and upload two versions of their manuscript. One should be a complete text, while in the second all document information identifying the author should be removed from files to allow them to be sent anonymously to referees. When uploading files authors will then be able to define the non-anonymous version as "File not for review".

Note to authors. Please make sure your contact address information is clearly visible on the outside of all packages you are sending to Editors. Authors should be mindful of the need to identify and reference quoted material - text, tables, and figures - clearly and consistently, and to secure written permission from the copyright holder as appropriate. http://tandf.tandf.co.uk/journals/ethics.asp

Free article access. As an author, you will receive free access to your article on Taylor \& Francis Online. You will be given access to the My authored works section of Taylor \& Francis Online, which shows you all your published articles. You can easily view, read, and download your published articles from there. In addition, if someone has cited your article, you will be able to see this information. We are committed to promoting and increasing the visibility of your article and have provided this guidance (http://journalauthors.tandf.co.uk/beyondpublication/ promotearticle.asp) on how you can help.

Reprints and journal copies. Corresponding authors will receive a complimentary copy of the issue containing their article. Reprints can be ordered through Rightslink ${ }^{\circledR}$ when proofs are received. If you have any queries about reprints, please contact the Taylor \& Francis Author Services team at reprints@tandf.co.uk. To order extra copies of the issue containing your article, please contact our Customer Services team at adhoc@tandf.co.uk.

Copyright. It is a condition of publication that all contributing authors grant to The Association for the Study of Nationalities the necessary rights to the copyright in all articles submitted to the Journal. Authors are required to sign an Article Publishing Agreement to facilitate this. This will ensure the widest dissemination and protection against copyright infringement of articles. The "article" is defined as comprising the final, definitive, and citable Version of Scholarly Record, and includes: (a) the accepted manuscript in its final and revised form, including the text, abstract, and all accompanying tables, illustrations, data; and $(b)$ any supplementary material. Copyright policy is explained in detail at http://journalauthors.tandf.co.uk/preparation/copyright.asp.

Authors are themselves responsible for obtaining permission to reproduce copyright material from other sources.

For further information about Taylor \& Francis journals please visit www.tandfonline.com.

If you are unable to access our websites, please write to: Nationalities Papers, Editorial Department, Taylor \& Francis, 4 Park Square, Milton Park, Abingdon, Oxon, OX14 4RN, UK.

THE ASSOCIATION FOR THE STUDY OF NATIONALITIES

New York

Phone: +12128546239

President

Vice-Presidents

Executive Director:

Secretary:

Chair of the Advisory Board:

President Emeritus:

Convention Program Chair:

European Conferences:

Executive Committee:

Zsuzsa Csergo, Queen's University, Canada

Vejas Liulevicius, University of Tennessee, USA

Ines Murzaku, Seton Hall University, USA

Gordon N. Bardos, Harriman Institute, Columbia U, USA

Lisa Koriouchkina, Brown University, USA

David Crowe, Elon University, USA

Michael Rywkin, City College, USA

Sherrill Stroschein, University College London, UK

Stefano Bianchini, University of Bologna, Italy

Dominique Colas, SciencesPo, Paris, France

Hugh Agnew, George Washington University, USA

Lowell Barrington, Marquette University, USA

Mark Beissinger, Princeton University, USA

Florian Bieber, Karl-Franzens-Universität Graz, Austria

Nina Caspersen, Lancaster University, UK

Bhavna Dave, School of Oriental \& African Studies, UK

Dmitry Gorenburg, AAASS, Cambridge, USA

Alexandra Goujon, University of Bourgogne, Dijon, France

Charles King, Georgetown University, USA

André Liebich, Graduate School of International Studies, Switzerland

Troy McGrath, Russian State University for the Humanities, Moscow, Russia

Michaela Pohl, Vassar College, USA

Steve Sabol, University of North Carolina, Charlotte, USA

Oxana Shevel, Tufts University, USA 


\section{Contents}

\section{Special Issue: Europeanization, State-Building and Democratization in the Western Balkans}

Guest Editor: Soeren Keil

\section{Introduction to Special Issue}

Europeanization, state-building and democratization in the Western Balkans

Soeren Keil

\section{Articles}

International statebuilding as contentious politics: the case of post conflict

Bosnia and Herzegovina

Outi Keranen

The OSCE Mission in Bosnia and Herzegovina: Testing the limits of ownership

Valery Perry and Soeren Keil

"Quadratic nexus" and the process of democratization and state-building in Albania and Kosovo:

a comparison

Gëzim Krasniqi

Cutting the mists of the Black Mountain: Cleavages in Montenegro's divide over statehood and identity Jelena Dzankic

The role of the EU in promoting good governance in Macedonia: towards efficiency and effectiveness or deliberative democracy?

Marija Risteska

Another "strategic accession"? The EU and Serbia (2000-2010)

Bernhard Stahl

EU Member State-Building in the Western Balkans: (Prolonged) EU-protectorates or new model of sustainable enlargement? Conclusion

Jens Woelk

Book Reviews 